BANDAZHEVSKY Yu. I. ${ }^{1}$, DUBOVAYA N. F. ${ }^{2 \bowtie}$

${ }^{1}$ PI Coordination and Analytical Center «Ecology and health», Ukraine, 07200, urban village Ivankov, Polysskay str., 65, e-mail: Yuri.by375@gmail.com

${ }^{2}$ Shupyk National Medical Academy of Postgraduate Education,

Ukraine, 04112, Kyiv, Dorohozhytskaya str., 9, e-mail: n_dubova@i.ua

$\bowtie n \_d u b o v a @ i . u a,(096) 225-97-00$

\title{
THE ROLE OF FOLATE METABOLISM GENOME IN THE FORMATION OF TRIIODOTHYRONINE IN CHILDREN LIVING IN AREAS AFFECTED BY THE CHERNOBYL NUCLEAR POWER PLANT ACCIDENT
}

\begin{abstract}
Aim. Aim of this study was to determine the role of the genome of folate metabolism in the formation of triiodothyronine in children living in areas affected by the Chernobyl nuclear power plant accident. Methods. Immunochemical, mathematical and statistical. Results. The proportion of cases of elevated blood levels of triiodothyronine is statistically significantly higher in the group of children who are carriers of the $\mathrm{G}$ risk allele of the MTR:A2756G genetic polymorphism associated with the $\mathrm{B}_{12}$-dependent methionine synthase enzyme than in the group of children who have no this allele (MTR:2756 A/A genotype). The formation of triiodothyronine is associated with the metabolic conversion of homocysteine involving vitamin $\mathrm{B}_{6}$ as a cofactor of cystathionine $\beta$-synthase. Conclusions. The cause of thyrotoxic effects with damage to the cardiovascular system may lie in high levels of homocysteine occurring due to impaired functioning of $\mathrm{B}_{12}$-dependent methionine synthase. Keywords: folate metabolism, triiodothyronine, genetic polymorphisms, radiationcontaminated areas.
\end{abstract}

The genome of folate metabolism (FM) plays a great role in metabolic processes of the human body [1]. It is important to determine its connection with pathological processes widely spread among the population living in areas of the BelarusianUkrainian Polesie under conditions of radiation exposure [2,3] and marked iodine deficiency [4]. In particular, this relates to thyroid diseases reported among children and adults 30 years after the Chernobyl nuclear power plant (CNPP) accident. The aim of this study was to determine the role of the genome of folate metabolism in the formation of triiodothyronine $\left(\mathrm{T}_{3}\right)$ in children living in areas affected by the CNPP accident.

\section{Material and methods}

The study was conducted in Ukraine with the support of the Children of Chernobyl association (France).

67 children (26 boys and 41 girls) from Polessky and Ivankovsky districts of Kyiv region located near the CNPP underwent laboratory and instrumental examination. According to data of dosimetry certification of settlements, the territory of the raions has remained contaminated with radioactive substances after the Chernobyl accident until the present day (having the ${ }^{137} \mathrm{Cs}$ soil contamination density of 0.17 up to 1.9 $\left.\mathrm{Cu} / \mathrm{km}^{2}\right)$ [2].

The children's average age at the time of examination was $11.7 \pm 0.33$ years $(95 \%$ CI 11.02 12.35 years). All the children who attended school had blood drawn from the ulnar vein after fasting in the morning. The blood samples were analysed at a laboratory certified under quality standards with the agreement of the parents. Thus, we assessed blood levels of free $\mathrm{T}_{3}$ and the state of the genetic system of FM.

$\mathrm{T}_{3}$ concentrations were determined using an electrochemiluminescent immunoassay (ECLIA) method. Analyser and test kit: Cobas 6000; Roche Diagnostics (Switzerland).

The following allelic variants were identified during genetic analysis of FM: C677T and A1298C of the MTHFR gene (synthesis of the methylenetetrahydrofolate reductase enzyme), A2756G of the MTR gene (synthesis of the $B_{12-}$ dependent methionine synthase enzyme) and A66G of the MTRR gene (synthesis of the methionine synthase reductase enzyme). A real-time PCR method was used. Analyser and test kit: DT-96 detecting thermocycler, DNA-Technology (Russia).

In the course of the study, we compared proportions of cases with blood $\mathrm{T}_{3}$ concentrations > $4.8 \mathrm{pg} / \mathrm{ml}$ in groups of children with carriership of

\footnotetext{
${ }^{\circ}$ BANDAZHEVSKY Yu. I., DUBOVAYA N. F.
} 
and the absence of risk alleles of the FM genetic polymorphisms under analysis.

The statistical processing of the results obtained was performed using the IBM SPSS Statistics 22 software (USA). The arithmetic mean $(\mathrm{M}), \pm$ standard error of mean $(\mathrm{m})$, confidence interval for the mean value $(95 \% \mathrm{CI})$, median (Me), interquartile range (IR), minimum and maximum parameter values and percentiles were calculated for the variables analysed. The statistical significance of variables was assessed by determining a significance level for $p$ with the help of the statistical software programme.

The Student's t-test was used to compare relative values. The critical level of significance for the null hypothesis $(p)$ was set at 0.05 .

\section{Results and discussion}

Previously conducted studies have shown a large number of children with genetic disorders of FM living in raions affected by the CNPP accident (Table 1).

Increased blood $\mathrm{T}_{3}$ levels $>4.8 \mathrm{pg} / \mathrm{ml}$ were detected in 27 out of 67 children examined $(40.3 \%)$.

The proportion of cases with blood $\mathrm{T}_{3}$ levels $>4.8 \mathrm{pg} / \mathrm{ml}$ is statistically significantly higher in the group of children who are carriers of the G risk allele of the MTR:A2756G genetic polymorphism associated with the $\mathrm{B}_{12}$-dependent methionine synthase enzyme than in the group of children who have no this allele (MTR:2756 A/A genotype) (Table 2).

It has been previously shown that in children with the MTR:2756 GG genotype blood homocysteine levels are statistically significantly lower than in those with the MTR:2756 A/A genotype (Table 3), and the proportion of cases of hyperhomocysteinemia is lower than in most groups of children with other folate metabolism genotypes (Table 4) [5].

In addition, a strong inverse association was detected between homocysteine and vitamin $\mathrm{B}_{12}$, and there was a strong direct association between homocysteine and vitamin $\mathrm{B}_{6}$ (Table 5) [6].

A strong inverse association was found between vitamins $\mathrm{B}_{6}$ and $\mathrm{B}_{12}$ (Table 6) [7].

The mentioned associations illustrate the possibility of the metabolic conversion of homocysteine to cystathionine, and then to cysteine involving the cystathionine $\beta$-synthase enzyme where vitamin $\mathrm{B}_{6}$ is a cofactor. The subsequent binding of cysteine with selenium leads to the formation of selenocysteine which forms the active center of deiodinase 5-DI involved in conversion of $\mathrm{T}_{4}$ to $\mathrm{T}_{3}$. Increased activity of 5-DI leads to enhanced formation of $\mathrm{T}_{3}$, which in large quantities has a toxic effect on the vital systems of the body (hyperthyroidism), including the cardiovascular system [8]. In addition, an increase in the influence of the sympathoadrenal system on the heart and blood vessels occurs, in particular, through increasing the number of $\mathrm{B}$-adrenergic receptors in the heart muscle and increasing the rate of noradrenaline turnover in synapses.

Moreover, the effect of $\mathrm{T}_{3}$ on the cardiac activity manifests itself through genomic mechanisms of regulation of the synthesis of $\mathrm{Na}^{+}$, $\mathrm{K}^{+}$- ATP-ase, atrial natriuretic hormone, alphaactin, and malate dehydrogenase. The permeability of sarcoplasmic reticulum membranes for $\mathrm{Ca}^{++}$ increases, which ensures a higher rate of release of the latter into the sarcoplasm. The permeability of plasma membranes of cells of the primary pacemaker changes. The activity of oxidativephosphorylation enzymes increases in mitochondria. At the same time, the heart rate increases. The occurring changes in hemodynamics by their nature adapt to increased metabolism. Not only tachycardia at rest and during sleep, but also cardiac arrhythmia is reported. Sinus tachycardia and arrhythmia are seen on ECGs [8, 9]. This results in abnormal cardiac activity.

Table 1. Frequency of polymorphic alleles of folate metabolism genes in the examined group of children $(\mathrm{n}=67)$

\begin{tabular}{|l|c|c|c|c|}
\hline \multirow{2}{*}{ Gene, polymorphism } & \multicolumn{2}{|c|}{ «Neutral» allele } & \multicolumn{2}{c|}{ Risk allele } \\
\cline { 2 - 5 } & Absolute number (n) & Percentage, $\%$ & Absolute number (n) & Percentage, \% \\
\hline MTR:A2756G & 39 & 58.2 & 28 & 41.8 \\
\hline MTHFR:A1298C & 24 & 35.8 & 43 & 64.2 \\
\hline MTHFR:C677T & 31 & 46.3 & 36 & 53.7 \\
\hline MTRR:A66G & 11 & 16.4 & 56 & 83.6 \\
\hline
\end{tabular}


The role of folate metabolism genome in the formation of triiodothyronine in children living in areas affected ...

Table 2. Proportion of cases with blood $\mathrm{T}_{3}$ concentrations $>4.8 \mathrm{pg} / \mathrm{ml}$ in groups of children with different genotypes

\begin{tabular}{|l|c|c|c|}
\hline \multirow{2}{*}{ Genotype } & \multirow{2}{*}{$\begin{array}{c}\text { Number of } \\
\text { cases }\end{array}$} & \multicolumn{2}{c|}{$\begin{array}{c}\text { Number of cases with blood } \mathrm{T}_{3} \\
\text { concentrations }>4.8 \mathrm{pg} / \mathrm{ml}\end{array}$} \\
\cline { 3 - 4 } & & Absolute number & $\%$ \\
\hline MTR:2756 A/G + MTR:2756 G/G & 28 & 16 & 57.1 \\
\hline MTR:2756 A/A & 39 & 11 & 28.2 \\
\hline MTHFR:1298 A/C +MTHFR:1298 C/C & 43 & 18 & 41.9 \\
\hline MTHFR:1298 A/A & 24 & 9 & 37.5 \\
\hline MTHFR:677 C/T + MTHFR:677 T/T & 36 & 14 & 38.5 \\
\hline MTHFR:677 C/C & 31 & 13 & 41.9 \\
\hline MTRR:66 A/G + MTRR:66 G/G & 56 & 22 & 39.3 \\
\hline MTRR:66 A/A & 11 & 5 & 45.5 \\
\hline
\end{tabular}

Note. Statistical differences between groups of children having A (genotype A/A) and G alleles of MTR:2756 genetic polymorphism $(\mathrm{t}=2.44 ; \mathrm{p}=0.022411)$.

Table 3. Statistical characteristics of homocysteine values in groups of children with folate metabolism genetic polymorphisms

\begin{tabular}{|c|c|c|c|c|c|c|}
\hline \multirow{2}{*}{$\begin{array}{c}\text { Polymorphism, } \\
\text { genotype }\end{array}$} & \multicolumn{5}{|c|}{ Hc, $\mu \mathrm{mol} / \mathrm{L}$} \\
\cline { 3 - 8 } & $\mathrm{n}$ & $\mathrm{Me}$ & $\mathrm{IR}$ & $\begin{array}{c}\text { Average } \\
\text { rank }\end{array}$ & $\begin{array}{c}\text { Mann-Whitney U test, } \\
\text { significance level }\end{array}$ \\
\hline \multirow{2}{*}{ MTR:A2756G } & AA & 163 & 12.1 & $10.3-14.4$ & 91.1 & $632.5 ;$ \\
\cline { 2 - 7 } & GG & 13 & 11.4 & $8.7-11.8$ & 55.7 & $\mathrm{p}=0.016$ \\
\hline
\end{tabular}

Table 4. Proportion of cases of hyperhomocysteinemia in groups of children

\begin{tabular}{|c|l|c|c|c|c|}
\hline \multirow{2}{*}{$\begin{array}{c}\text { Subgroup } \\
\text { No. }\end{array}$} & \multirow{2}{*}{$\begin{array}{c}\text { Polymorphisms, } \\
\text { genotypes }\end{array}$} & $\begin{array}{c}\text { Absolute } \\
\text { number }\end{array}$ & $\begin{array}{c}\text { Percentage, } \\
\%\end{array}$ & $\begin{array}{c}\text { Absolute } \\
\text { number }\end{array}$ & $\begin{array}{c}\text { Percentage, } \\
\%\end{array}$ \\
\hline 1 & MTR:2756GG & 13 & 4.9 & 7 & 53.9 \\
\hline 2 & MTR:2756AG & 87 & 33.1 & 66 & 75.9 \\
\hline 3 & MTR:2756AA & 163 & 62.0 & 125 & 76.7 \\
\hline 4 & MTHFR:1298CC & 21 & 8.0 & 11 & 52.4 \\
\hline 5 & MTHFR:1298AC & 105 & 39,9 & 81 & 77.1 \\
\hline 6 & MTHFR:1298AA & 137 & 52.1 & 105 & 76.6 \\
\hline 7 & MTHFR:677TT & 26 & 9.9 & 23 & 88.5 \\
\hline 8 & MTHFR:677CT & 112 & 42.6 & 87 & 77.7 \\
\hline 9 & MTHFR:677CC & 125 & 47.5 & 88 & 70.4 \\
\hline 10 & MTRR:66GG & 88 & 33.5 & 70 & 79.6 \\
\hline 11 & MTRR:66AG & 131 & 49.8 & 98 & 74.8 \\
\hline 12 & MTRR:66AA & 44 & 16.7 & 30 & 68.2 \\
\hline 13 & 677CT/1298AC & 47 & 17.9 & 39 & 83.0 \\
\hline
\end{tabular}


Table 5. Spearman's correlation coefficients between serum homocysteine and vitamins $\mathrm{B}_{6}, \mathrm{~B}_{9}$ and $\mathrm{B}_{12}$ levels in a total group of children

\begin{tabular}{|c|c|l|c|c|c|}
\hline \multirow{2}{*}{ Genotype } & \multirow{2}{*}{ Parameter } & \multicolumn{1}{|c|}{$\begin{array}{c}\text { Correlation coefficient }\left(\mathrm{r}_{\mathrm{xy}}\right), \\
\text { significance, } p\end{array}$} & \multicolumn{3}{|c|}{ Parameters } \\
\cline { 3 - 6 } & & \multicolumn{1}{|c|}{$\mathrm{B}_{6}$} & $\mathrm{~B}_{9}$ & $\mathrm{~B}_{12}$ \\
\hline \multirow{3}{*}{ MTR: 2756GG } & \multirow{3}{*}{$\mathrm{H}_{\mathrm{c}}$} & Spearman's & $0.724^{*}$ & -0.309 & $-0.918^{* *}$ \\
\cline { 3 - 6 } & & Sign. (2-tailed) & 0.012 & 0.355 & 0.00001 \\
\cline { 3 - 6 } & $\mathrm{N}$ & 11 & 11 & 11 \\
\hline
\end{tabular}
0.01 level.

Notes: $\mathrm{H}_{\mathrm{c}}-$ homocysteine; $*$ - correlation is significant at the 0.05 level; ** - correlation is significant at the

Table 6. Spearman's correlation coefficient between serum levels of vitamins $\mathrm{B}_{6}$ and $\mathrm{B}_{12}$ in a subgroup of children with MTR:2756GG genotype who are not carriers of T allele of MTHFR:C677T polymorphism

\begin{tabular}{|c|c|l|c|}
\hline \multirow{2}{*}{ Genotype } & Parameter & \multicolumn{1}{c|}{$\begin{array}{c}\text { Correlation coefficient }\left(\mathrm{r}_{\mathrm{xy}}\right), \\
\text { significance, } p\end{array}$} & \begin{tabular}{c} 
Parameters \\
\cline { 3 - 4 } MTR:2756GG
\end{tabular} \\
& \multirow{3}{*}{$\mathrm{B}_{6}$} & Spearman's & $-0.829^{*}$ \\
\cline { 3 - 4 } & & Sign. (2-tailed) & 0.042 \\
\cline { 3 - 4 } & $\mathrm{N}$ & 6 \\
\hline
\end{tabular}

Note. ${ }^{*}$ - correlation is significant at the 0.05 level.

In the presence of iodine deficiency, increased activity of 5-DI leads to acceleration of metabolism of $\mathrm{T}_{4}$ and worsening of the course of hyperthyroidism since the thyroid gland can not compensate for the accelerated metabolism of $\mathrm{T}_{4}$. In relation to the $\mathrm{T}$ allele of the MTHFR:C677T genetic polymorphism this association was not detected $[6,7]$.

Thus, the genetic block of conversion of homocysteine to methionine at the level of the $\mathrm{B}_{12^{-}}$ dependent methionine synthase enzyme in the form of the MTR $2756 \mathrm{G}$ mutation activates the process of conversion of homocysteine to cysteine and selenocysteine and increased formation of $\mathrm{T}_{3}$. As a result of this, there is a violation of the cardiovascular system.

Children with the mentioned genetic defect should be included in the risk group in terms of the possible occurrence of cardiac abnormalities in order to carry out the necessary preventive measures.

\section{Conclusions}

1. The proportion of cases of elevated blood levels of triiodothyronine is statistically significantly higher in the group of children who are carriers of the $\mathrm{G}$ risk allele of the MTR:A2756G genetic polymorphism associated with the $B_{12^{-}}$ dependent methionine synthase enzyme than in the group of children who have no this allele (MTR:2756 A/A genotype).

2. The formation of triiodothyronine is associated with the metabolic conversion of homocysteine involving vitamin $\mathrm{B}_{6}$ as a cofactor of cystathionine $\beta$-synthase.

3. The cause of thyrotoxic effects with damage to the cardiovascular system may lie in high levels of homocysteine occurring due to impaired functioning of $\mathrm{B}_{12}$-dependent methionine synthase.

\section{References}

1. Koh N.F., Sleuhina A.A., Livshits G.I. Folatnii tsikl: obzor i prakticheskie rekomendatsii po interpretatsii geneticheskih testov. Meditsinskaya genetika. 2015. № 11. S. 3-8. [in Russian] / Кох Н.Ф., Слеухина А.А., Лившиц Г.И. Фолатный цикл: обзор и практические рекомендации по интерпретации генетических тестов. Медицинская генетика. 2015. № 11. С. 3-8.

2. Zagal'nodozimetrichna pasportizatsiya ta rezul'tati LVL-monitoringu $\mathrm{v}$ naselenih punktah Ukraïni, yaki zaznali radioaktivnogo zabrudnennya pislya Chornobil's'koï katastrofi. Dani za 2011 r. Zbirka 14. K.: MOZ Ukraïni, NAMNU Ukraïni, MNS Ukraïni, DAZV, DU "NNTSRM NAMN Ukraïni", ND IRZ ATN Ukraïni, 2012. 99 s. [in Ukrainian] / Загальнодозиметрична паспортизація та результати ЛВЛ-моніторингу в населених пунктах України, які зазнали радіоактивного забруднення після Чорнобильської катастрофи. Дані за 2011 р. Збірка 14. К.: МОЗ України, НАМНУ України, МНС України, ДАЗВ, ДУ «ННЦРМ НАМН України», НД ІРЗ АТН України, 2012. 99 с.

3. 25 rokiv Chornobil's'koï katastrofi. Bezpeka maibutn'ogo: Natsional'na dopovid' Ukraini. K.: KIM, 2011.356 s. [in Ukrainian] / 25 років Чорнобильської катастрофи. Безпека майбутнього: Національна доповідь України. К.: КІМ, $2011.356 \mathrm{c}$.

4. Mamenko M.E. Ioddefitsitni zahvoryuvannya v ditei na shodi Ukraini: cuchasnii stan problemi ta shlyahi virishennya. Mezhdunarodnii endokrinologicheskii zhurnal. 2008. T. 3, № 15. S. 16-21. [in Ukrainian] / Маменко М.Э. Йоддефіцитні 
The role of folate metabolism genome in the formation of triiodothyronine in children living in areas affected ...

захворювання в дітей на сході Украіни: сучасний стан проблеми та шляхи вирішення. Международный эндокринологический журнал. 2008. Т. 3, № 15. С. 16-21.

5. Bandazhevsky Yu.I., Dubova N.F. The role of genome of folate metabolism in the occurrence of hyperhomocysteinemia in children from the areas affected by the Chernobyl nuclear power plant accident. Scientific and practical collection «Chernobyl: ecology and health». Issue 6. Ivankov: PI Coordination and Analytical Center «Ecology and health», Dnipro: Serednyak T.K., 2017. P. 27-35.

6. Bandazhevsky Yu.I., Dubova N.F. The genotype of the folate cycle and the correlation between metabolic rates in children living in areas affected by the Chernobyl nuclear power plant. Scientific and practical collection «Chernobyl: ecology and health». Issue 7. Ivankov: PI Coordination and Analytical Center «Ecology and health», Dnipro: Serednyak T.K., 2018. P. 1829.

7. Bandazhevsky Yu.I., Dubova N.F. Correlation relations between vitamins $\mathrm{B}_{6}, \mathrm{~B}_{9}$ and $\mathrm{B}_{12}$ in different genotypes of the folate cycle, in children from the area affected by the accident at the Chernobyl nuclear power plant. Scientific and practical collection "Chernobyl: ecology and health». Issue 7. Ivankov: PI Coordination and Analytical Center «Ecology and health», Dnipro: Serednyak T.K., 2018. P. 29-38.

8. Biondi B., Palmieri Emiliano A., Lombardi Gaetano, Fazio Serafino Effects of Thyroid Hormone on Cardiac Function: The Relative Importance of Heart Rate, Loading Conditions, and Myocardial Contractility in the Regulation of Cardiac Performance in Human Hyperthyroidism. J. Clin. Endocrinol. Metab. 2002. Vol. 87 (3). P. 968-974.

9. Schitovidnaya zheleza. Fundamental'nie aspekti / Pod red. prof. A.I. Kubarko i prof. S. Yamashita. Minsk - Nagasaki, 1998. 368 s. [in Russian] / Щитовидная железа. Фундаментальные аспекты / Под ред. проф. А.И. Кубарко и проф. S. Yamashita. Минск - Нагасаки, 1998. 368 с.

БАНДАЖЕВСЬКИЙ Ю. І. ${ }^{1}$, ДУБОВА Н. Ф. ${ }^{2}$

${ }^{1}$ Координаційно-аналітичний центр «Екологія та здоров'я»,

Україна, 07200, смт. Іванків, вул. Поліська, 65, е-таil: Yuri.by375@gтаil.com

${ }^{2}$ Національна медична академія післядипломної освіти ім. П.Л. Шупика МОз Украӥни,

Україна, 04112, м. Київ, вул. Дорогожиџька, 9, е-таil: n_dubоvа@і.иа

\section{РОЛЬ ГЕНОМУ ФОЛАТНОГО ЦИКЛУ В УТВОРЕННІ ТРИЙОДТИРОНІНА У ДІТЕЙ, ЯКІ ПРОЖИВАЮТЬ НА ТЕРИТОРІЇ, ЩО ПОСТРАЖДАЛА ВІД АВАРІЇ НА ЧОРНОБИЛЬСЬКІЙ АТОМНІЙ ЕЛЕКТРОСТАНЦІї}

Mema. Метою цього дослідження було визначення ролі геному фолатного циклу в утворенні трийодтироніну у дітей, які проживають на території, що постраждала від аварії на Чорнобильській атомній електростанції. Memodu. Імунохімічний, математико-статистичний. Результати. Питома вага випадків підвищеного вмісту в крові трийодтироніну в групі дітей-носіїв алелі ризику G генетичного поліморфізму MTR:A2756G, пов'язаного 3 ферментом $\mathrm{B}_{12}$-залежна метіонін-синтаза, була достовірно більшою, ніж у групі дітей, які не мають цієї алелі генотип A/A MTR:2756. Утворення трийодтироніну пов'язане з метаболічними перетвореннями гомоцистеїну за участю вітаміну $\mathrm{B}_{6}$ в якості кофактора ферменту цистатіонін- $\beta$-синтази. Висновки. Причиною тиреотоксичних ефектів з ураженням серцево-судинної системи може бути високий рівень гомоцистеїну, пов'язаний з порушенням функціонування $\mathrm{B}_{12}$-залежної метіонін-синтази.

Ключові слова: фолатний цикл, трийодтиронін, генетичні поліморфізми, радіоактивно забруднена територія. 